\title{
BIOAVAILABILITAS FORTIFIKAN, DAYA CERNA PROTEIN, SERTA KONTRIBUSI GIZI BISKUIT YANG DITAMBAH TEPUNG IKAN GABUS (Ophiocephalus striatus) DAN DIFORTIFIKASI SENG DAN BESI
}

\author{
Fortificant Bioavailability, Protein Digestibility, and Nutrient Contribution of Biscuit Containing Snakehead \\ (Ophiocephalus striatus) Fish Flour and Fortified with Zinc and Iron
}

\section{Dewi Kartika Sari ${ }^{1}$, Sri Anna Marliyati², Lilik Kustiyah², Ali Khomsan², Tommy Marcelino Gantohe ${ }^{2}$}

\author{
${ }^{1}$ Program Studi Teknologi Hasil Perikanan, Universitas Lambung Mangkurat, Jl. Jendral Ahmad Yani Km. 36, Banjarbaru 70714 \\ ${ }^{2}$ Departemen Gizi Masyarakat, Fakultas Ekologi Manusia, Institut Pertanian Bogor, Jl. Kamper, \\ Kampus IPB Darmaga, Bogor 16680 \\ Email: kartikarofian@yahoo.co.id
}

\begin{abstract}
ABSTRAK
Penelitian ini bertujuan untuk mempelajari bioavailabilitas fortifikan, daya cerna protein, dan kontribusi gizi biskuit ikan gabus yang ditambahkan tepung ikan gabus dan difortifikasi dengan $\mathrm{Zn}$ dan Fe. Rancangan percobaan yang digunakan adalah RAL. Penelitian terdiri atas dua tahap, yaitu pertama adalah melakukan mikroenkapsulasi mineral $\mathrm{Zn}$ dan $\mathrm{Fe}$, kedua formulasi biskuit berbasis 15\% tepung ikan gabus yang difortifikasi dengan mineral $\mathrm{Zn}$ dan $\mathrm{Fe}$ dengan taraf fortifikasi, yaitu sebesar $25 \%, 50 \%$, dan $100 \%$ AKG per serving size. Terhadap biskuit yang dihasilkan dilakukan analisis bioavailabilitas $\mathrm{Zn}$ dan Fe. Hasil sidik ragam menunjukkan bahwa bioavailabilitas $\mathrm{Zn}$ dan $\mathrm{Fe}$ tidak berbeda nyata pada berbagai taraf fortifikasi ( $p>0.05$ ). Biskuit hasil fortifikasi $\mathrm{Zn}$ dan Fe sebesar $50 \%$ AKG memiliki bioavailabilitas tertinggi, yaitu masing-masing $76,32 \%$ dan $41,80 \%$. Formula biskuit ini dipilih untuk dianalisis lebih lanjut, yang meliputi analisis sifat fisik, kimia, dan daya cerna protein. Hasil analisis menunjukkan bahwa biskuit terpilih tersebut lebih renyah daripada biskuit komersial. Dalam $100 \mathrm{~g}$ biskuit tersebut terkandung air, abu, protein, lemak, dan karbohidrat berturut-turut sebesar 2,73 g; 2,08 g; 13,34 g; 24,53 g; 57,32 g; serta energi sebesar 503 kkal. Kadar $\mathrm{Fe}$ dan $\mathrm{Zn}$ biskuit terpilih tersebut adalah $11,7 \mathrm{mg}$ dan $8,83 \mathrm{mg} / 100 \mathrm{~g}$; dengan daya cerna protein sebesar $78,45 \%$. Biskuit berbasis tepung ikan gabus 15\% yang difortifikasi Zn dan Fe sebesar 50\% AKG memenuhi standar kualitas biskuit SNI 01-2973-1992. Kontribusi biskuit terpilih terhadap AKG energi, protein, Fe dan Zn berturut-turut adalah $19,48 \% ; 20,51 \% ; 74,44 \% ; 54.44 \%$.
\end{abstract}

Kata kunci: Bioavailabilitas, biskuit ikan gabus, daya cerna protein, fortifikasi

\begin{abstract}
This research aimed to evaluate the bioavailability of fortificant, protein digestibility, and nutrition contribution of biscuits supplemented with snakehead fish flour and fortified with $\mathrm{Zn}$ and Fe. Randomized complete design was used in this research which consisted of two steps, namely: 1) $\mathrm{Zn}$ and Fe microencapsulation, 2) formulation of biscuit supplemented with fish flour 15\% which fortified with $\mathrm{Zn}$ and Fe. Level of $\mathrm{Zn}$ and Fe per serving size were to meet $25 \%, 50 \%$ and $100 \%$ of RDA. Based on ANOVA showed that there were no significantly difference on bioavailability of $\mathrm{Zn}$ and $\mathrm{Fe}$ on various fortification level ( $\mathrm{p}>0.05$ ). Biscuits fortified with $\mathrm{Zn}$ and Fe to meet $50 \%$ RDA per serving size had the highest bioavailability of $76.32 \%$ and $41.80 \%$, respectively. This biscuits was chosen for further analysis namely physical and chemical characteristics and protein digestibility. Result of analysis showed that the chosen biscuits more crunchy than those the commercial biscuits. Each a hundred grams of biscuits contained moisture, ash, protein, fat, carbohydrate, energy, Fe and $\mathrm{Zn}$ of about $2.73 \mathrm{~g}, 2.80 \mathrm{~g}, 13.34 \mathrm{~g}, 24.53 \mathrm{~g}, 57.32 \mathrm{~g}, 503 \mathrm{kcal}, 11.7 \%$ and 8.83\%, respectively and had protein digestibility of $78.45 \%$. This biscuits was in range of quality standards for biscuits SNI 01-2973-1992. The contribution of the chosen biscuits on RDA of energy, protein, Fe and Zn were 19,48\%; 20,51\%; $74,44 \% ; 54.44 \%$, respectively.
\end{abstract}

Keywords: Bioavailability, biscuit of snakehead fish, protein digestability, fortification 


\section{PENDAHULUAN}

Data Riskesdas 2010 menunjukkan bahwa persentase anak dengan konsumsi energi dan protein kurang dari $70 \%$ AKG adalah $33,4 \%$, dari jumlah tersebut $24,8 \%$ berada pada kelompok umur 4-6 tahun. Sebagian besar kasus konsumsi energi protein yang berada di bawah kebutuhan minimal terjadi di daerah pedesaan dan cenderung lebih besar pada kelompok anak laki-laki (Badan Penelitian dan Pengembangan Kesehatan, 2010). Masalah gizi kurang dan buruk masih perlu mendapat perhatian. Gizi buruk yang berkelanjutan dapat meningkatkan angka kematian anak. Diperkirakan 7\% anak balita Indonesia (sekitar 300.000 jiwa) meninggal setiap tahun, ini berarti setiap 2 menit terjadi kematian satu anak balita dan 170.000 anak (60\%) diantaranya akibat gizi buruk (Badan Penelitian dan Pengembangan Kesehatan, 2007). Pada kasus gizi buruk, defisiensi protein akan menurunkan kualitas hidup individu dengan efek penurunan sistem imun (Susanto dan Maslikah, 2011). Masukan protein dari diet dapat menstimulasi sintesis albumin serum yang berperan dalam regulasi protein tubuh (Caso dkk., 2000).

Protein hewani diketahui bermutu tinggi karena mengandung asam-asam amino esensial yang lengkap dengan susunan yang sesuai dengan kebutuhan tubuh dan daya cerna protein yang tinggi (Muchtadi, 2010). Salah satu bahan pangan sumber protein hewani adalah ikan gabus (Ophiocephalus striatus). Menurut Santosa (2001) dan Nurilmala dkk. (2009), kadar protein ikan gabus adalah 25,5\%; yang berarti lebih tinggi daripada ikan sarden $(21,1 \%)$, ikan bandeng (20,0\%), ikan kakap (20,0\%), ikan lele $(17,71 \%)$, dan ikan emas (16,0\%). Astawan (2009) mengungkapkan bahwa kadar protein ikan gabus lebih tinggi daripada telur, daging ayam dan daging sapi; ketiganya memiliki kadar protein berturutturut sebesar 12,8; 18,2; dan 18,8 g/100g.

Sama seperti ikan pada umumnya, ikan gabus bersifat mudah busuk. Penepungan merupakan salah satu cara untuk mengatasi hal tersebut, selain meningkatkan nilai tambah ikan. Dalam bentuk tepung, ikan dapat dengan mudah dimanfaatkan untuk substitusi sebagian tepung terigu, antara lain pada pembuatan biskuit sehingga dapat meningkatkan nilai gizi produk tersebut.

Dewasa ini banyak dijumpai balita dengan gizi kurang, yang mempunyai kadar albumin darah yang rendah serta menderita defisiensi gizi mikro, antara lain $\mathrm{Zn}$ dan Fe. Ikan gabus merupakan sumber albumin yang potensial (Moedjiharto, 2007). Biskuit dengan substitusi tepung ikan gabus dan difortifikasi menggunakan $\mathrm{Zn}$ dan Fe dapat menjadi pilihan untuk digunakan sebagai makanan tambahan balita gizi kurang. Oleh karena itu perlu dilakukan penelitian untuk mengetahui pengaruh substitusi tepung ikan gabus dan difortifikasi dengan Zn dan Fe terhadap bioavailabilitas fortifikan, daya cerna protein, dan kontribusi gizi biskuit.

\section{METODE PENELITIAN}

\section{Bahan dan Alat}

Bahan utama penelitian adalah tepung ikan gabus segar yang diperoleh dari perairan di Kalimantan Selatan, sebagai sumber mineral $\mathrm{Zn}$ dan $\mathrm{Fe}$ digunakan $\mathrm{ZnSO}_{4} 7 \mathrm{H}_{2} \mathrm{O}$ dan $\mathrm{FeSO}_{4} 7 \mathrm{H}_{2} \mathrm{O}$. Bahan penyalut mikroenkapsulan $\mathrm{Zn}$ dan Fe digunakan gum arab dan maltodekstrin, dengan proses mikroenkapsulasi menggunakan spray dryer. Menurut Herman dkk. (2002), seng sulfat sebagai fortifikan memiliki kelarutan dalam adonan dan penyerapan lebih baik daripada bentuk seng oksida. Bahan baku untuk biskuit adalah tepung terigu, tepung ikan gabus, gula halus, keju, cokelat bubuk, maizena, mentega dan margarin.

Adapun alat yang digunakan antara lain adalah neraca analitik, spray drier, mixer, cetakan biskuit, texture analyzer, spektrofotometer, Atomic Absorption Spectrophotometer (AAS), dan peralatan untuk analisis kadar protein, lemak, air, serta abu.

\section{Mikroenkapsulasi Zn dan Fe dengan Spray Drying}

Rasio gum arab dan maltodekstrin untuk penyalut mineral adalah 70:30 (b/b) untuk Fe dan 80:20 (b/b) untuk $\mathrm{Zn}$. Perbedaan rasio gum arab terhadap maltodekstrin dilakukan dengan tujuan untuk mencegah interaksi negatif $\mathrm{Fe}$ dan Zn di dalam usus (Kustiyah dkk., 2010). Mineral yang digunakan sebagai inti mikrokapsul ini adalah fero sulfat dan seng sulfat.

Mikrokapsulasi mineral dilakukan dengan metode spray drying (Desai dan Park, 2005; Purnamasari, 2009). Mikrokapsulasi dengan teknik spray drying memiliki tiga tahapan utama, yaitu persiapan emulsi, homogenisasi dispersi, dan atomisasi (Desai dan Park, 2005). Tahap persiapan emulsi dilakukan dengan mencampurkan maltodekstrin, gum arab, dan senyawa fortifikan dengan metode dry mixing. Dry mixing dilakukan dengan mencampurkan mineral dengan konsentrasi 7,5\% dari total penyalut (Kustiyah dkk., 2010). Konsentrasi mineral tehadap penyalut sebanyak $5-10 \%$ memberikan efisiensi kapsulasi yang tinggi pada produk tepung (Fitriani, 2001). Setelah diperoleh campuran bubuk mineral dan penyalut yang homogen maka campuran kering dilarutkan dengan menggunakan akuades dan dihomogenisasi dengan homogenizer, tahap ini disebut dengan pembuatan dispersi. Pengadukan dengan homogenizer bertujuan untuk membentuk droplet-droplet kecil mineral yang telah berikatan dengan penyalut. Tahap akhir dari proses enkapsulasi adalah pengeringan dengan menggunakan spray dryer, dengan Suhu 
pengeringan masuk $170^{\circ} \mathrm{C}$ dan suhu pengering keluar $85^{\circ} \mathrm{C}$ (Purnamasari, 2009).

\section{Formulasi Biskuit Fungsional yang Difortifikasi Zn dan Fe}

Rancangan percobaan pada penelitian ini adalah RAL (Rancangan Acak Lengkap) dengan formula biskuit berdasarkan hasil penelitian Marcelino (2012). Dalam pembuatan biskuit, $15 \%$ tepung terigu disubstitusi dengan tepung ikan gabus dengan dosis yaitu 0, 25, 50, dan $100 \%$ AKG/serving size. Berat biskuit satu serving size adalah 60 $\mathrm{g}$ atau sebanyak 6 keping biskuit, dengan ukuran per keping biskuit tebal $1 \mathrm{~cm}$ dan panjang $4 \mathrm{~cm}$.

Terhadap biskuit yang dihasilkan dilakuan beberapa uji, meliputi: (1) uji penerimaan panelis, (2) uji bioavailabilitas Fe dan Zn, dan (3) uji sifat fisik dan kimia, (4) kadar Zn dan Fe serta daya cerna protein biskuit terpilih.

Uji penerimaan panelis terhadap biskuit dengan menggunakan uji hedonik oleh 30 panelis semi terlatih (Soekarto, 1985). Adapun uji bioavailabilitas $\mathrm{Zn}$ dan $\mathrm{Fe}$ dilakukan dengan metode kantung dialisis (Damayanthi dan Rimbawan, 2008).

Uji sifat fisik yang dilakukan berupa uji kerenyahan biskuit menggunakan texture analyzer (Kumar dkk., 2010). Adapun ujian kimia yang dilakukan meliputi kadar air dengan metode gravimetrik (AOAC, 2000), kadar abu dengan metode pengabuan kering (AOAC, 2000), kadar protein dengan metode Kjeldahl (AOAC, 2000), lemak dengan metode Soxhlet (AOAC, 2000), dan karbohidrat (by different). Kadar $\mathrm{Zn}$ dan Fe dilakukan dengan menggunakan AAS (Salvin, 1986). Sedangkan daya cerna protein ditentukan secara in vitro (Saunders dkk., 1973).

\section{HASIL DAN PEMBAHASAN}

\section{Mikroenkapsulasi Zn dan Fe dengan Spray Drying}

Hasil pengamatan menunjukkan bahwa dari $20 \mathrm{~g}$ mineral Zn dan 939,39 g gum arab, serta 234,85 g maltodekstrin diperoleh berat total penyalut dan mineral sebesar 1.262,31 g. Setelah proses mikroenkapsulasi dihasilkan $675 \mathrm{~g}$ mikrokapsul $\mathrm{Zn}$ dengan kadar sebesar 2,98\%. Dari $20 \mathrm{~g}$ mineral Fe dan $926,73 \mathrm{~g}$ gum arab dan $397,17 \mathrm{~g}$ maltodekstrin diperoleh berat total penyalut dan mineral sebesar $1.423,19$ gram. Setelah proses mikroenkapsulasi dihasilkan 863 g mikrokapsul Fe dengan kadar Fe sebesar 1,96\%.

Pembuatan biskuit berbasis $15 \%$ tepung ikan gabus yang difortifikasi $\mathrm{Zn}$ dan Fe dengan cara melakukan homogenisasi mikrokapsul mineral dengan tepung terigu menggunakan metode pencampuran kering (dry mixing), setelah campuran homogen dilanjutkan penambahan tepung ikan gabus secara bertahap dengan tetap melakukan pengadukan. Formula biskuit ikan dengan penambahan mikroenkapsulan $\mathrm{Zn}$ dan $\mathrm{Fe}$ menggunakan dosis yaitu 0, 25, 50, dan 100\% AKG/ serving size. Penentuan jumlah mikrokapsul yang ditambahkan ke dalam adonan pada setiap dosis perlakuan berdasarkan pada kadar Zn dan Fe, mikrokapsul untuk setiap serving size biskuit dapat dilihat pada Tabel 1.

Tabel 1. Jumlah mikrokapsul mineral per serving size biskuit pada setiap taraf

\begin{tabular}{lllll}
\hline \multirow{2}{*}{ Mikrokapsul } & \multicolumn{4}{l}{ Kadar fortifikan $(\%$ AKG/serving size $)$} \\
\cline { 2 - 5 } & 0 & 25 & 50 & 100 \\
\hline Seng (g) & 0 & 0,08 & 0,16 & 0,33 \\
Besi (g) & 0 & 0,10 & 0,20 & 0,41 \\
\hline
\end{tabular}

\section{Penerimaan Panelis terhadap Biskuit}

Nilai modus tingkat kesukaan panelis terhadap biskuit hasil substitusi dengan tepung ikan gabus dan difortifikasi $\mathrm{Zn}$ dan Fe dapat dilihat pada Tabel 2.

Tabel 2. Nilai modus dan persentase penerimaan panelis terhadap biskuit ikan gabus yang difortifikasi dengan $\mathrm{Zn}$ dan Fe

\begin{tabular}{lllll}
\hline \multirow{2}{*}{ Karakteristik } & \multicolumn{4}{c}{ Kadar fortifikan (\% AKG/serving size) } \\
\cline { 2 - 5 } & 0 & 25 & 50 & 100 \\
\hline Warna & $4(56,67)$ & $4(53,34)$ & $4(55,00)$ & $4(45,00)$ \\
Aroma & $3(50,00)$ & $3(52,00)$ & $4(48,34)$ & $4(43,34)$ \\
Rasa & $4(38,34)$ & $3(46,67)$ & $4(43,34)$ & $4(38,34)$ \\
Tekstur & $4(56,67)$ & $4(61,67)$ & $4(56,67)$ & $3(36,67)$ \\
Keseluruhan & $4(53,34)$ & $4(56,67)$ & $4(51,67)$ & $4(40,00)$ \\
\hline
\end{tabular}

Keterangan: Nilai berkisar antara 1 (sangat tidak suka) sampai dengan 5 (sangat suka)

Angka di dalam kurung menyatakan persentase panelis

Data pada Tabel 2 menunjukkan bahwa substitusi tepung terigu dengan 15\% tepung ikan gabus dan difortifikasi Zn dan Fe sampai dengan 100\% AKG tidak mempengaruhi penerimaan panelis terhadap warna biskuit serta penerimaan secara keseluruhan. Kadar fortifikan sebesar $100 \%$ AKG ternyata menurunkan peneriman panelis terhadap tekstur biskuit. Persentase penerimaan panelis terhadap biskuit ikan gabus yang difortifikasi $\mathrm{Zn}$ dan Fe dapat dilihat pada Tabel 3. 
Tabel 3. Persentase penerimaan panelis terhadap biskuit ikan gabus yang difortifikasi dengan $\mathrm{Zn}$ dan $\mathrm{Fe}$

\begin{tabular}{|c|c|c|c|c|c|}
\hline \multirow{2}{*}{$\begin{array}{c}\text { Kadar fortifikan } \\
(\% \mathrm{AKG} / \text { serving size })\end{array}$} & \multicolumn{5}{|c|}{$\begin{array}{l}\text { Persentase penerimaan panelis terhadap } \\
\text { karakteristik organoleptik }\end{array}$} \\
\hline & Warna (\%) & Rasa (\%) & Aroma (\%) & Tekstur (\%) & Keseluruhan (\%) \\
\hline 0 & $96,70^{\mathrm{a}}$ & $81,70^{\mathrm{a}}$ & $88,30^{\mathrm{a}}$ & $96,70^{\mathrm{a}}$ & $93,30^{\mathrm{a}}$ \\
\hline 25 & $95,00^{\mathrm{a}}$ & $91,70^{\mathrm{a}}$ & $85,00^{a}$ & $98,30^{\mathrm{a}}$ & $96,70^{\mathrm{a}}$ \\
\hline 50 & $98,30^{\mathrm{a}}$ & $88,30^{\mathrm{a}}$ & $96,70^{\mathrm{a}}$ & $95,00^{\mathrm{a}}$ & $93,30^{\mathrm{a}}$ \\
\hline 100 & $90,00^{\mathrm{a}}$ & $90,00^{\mathrm{a}}$ & $88,30^{\mathrm{a}}$ & $75,00^{\mathrm{a}}$ & $85,00^{\mathrm{a}}$ \\
\hline
\end{tabular}

Keterangan: Angka dengan superscript sama dalam satu lajur menunjukkan tidak berbeda nyata pada tingkat kepercayaan $5 \%$

Data pada Tabel 3 menunjukkan bahwa substitusi tepung terigu dengan $15 \%$ tepung ikan gabus dan difortifikasi $\mathrm{Zn}$ dan $\mathrm{Fe}$ pada biskuit tidak mempengaruhi penerimaan panelis terhadap warna, rasa, aroma, dan tekstur biskuit, serta penerimaan secara keseluruhan penelis terhadap biskuit tersebut. Menurut López dkk. (2003), Zn sulfat dapat digunakan dalam fortifikasi produk yang mengandung terigu dan aman untuk dikonsumsi. Mikrokapsulasi dapat meminimalkan dampak fortifikan terhadap mutu organoleptik pangan pembawa fortifikan. Hal ini sejalan dengan Rossana (2009) yang menyatakan bahwa mikrokapsul mineral tidak mempengaruhi mutu organoleptik produk pembawanya.

Selain uji hedonik, dilakukan juga uji mutu hedonik biskuit. Uji mutu hedonik tidak menyatakan suka atau tidak suka melainkan menyatakan kesan tentang baik atau buruk. Nilai modus penilaian panelis terhadap mutu hedonik biskuit dapat dilihat pada Tabel 4 .

Tabel 4. Nilai modus penilaian panelis terhadap mutu hedonik biskuit ikan gabus yang difortifikasi dengan $\mathrm{Zn}$ dan $\mathrm{Fe}$

\begin{tabular}{lcccc}
\hline \multirow{2}{*}{$\begin{array}{l}\text { Karakteristik } \\
\text { organoleptik }\end{array}$} & \multicolumn{4}{c}{ Kadar fortifikan (\% AKG/serving size) } \\
\cline { 2 - 5 } Warna & $3(35 \%)$ & $3(35 \%)$ & $3(38 \%)$ & $3(43 \%)$ \\
Aroma & $3(38 \%)$ & $4(35 \%)$ & $3(53 \%)$ & $3(33 \%)$ \\
Rasa & $4(38 \%)$ & $3(47 \%)$ & $4(42 \%)$ & $4(38 \%)$ \\
Tekstur & $4(58 \%)$ & $4(63 \%)$ & $4(63 \%)$ & $4(23 \%)$ \\
\hline
\end{tabular}

Keterangan: Angka di dalam kurung menyatakan persentase panelis pada taraf kepercayaan $5 \%$

Tabel 4 menunjukkan bahwa rerata modus penilaian mutu hedonik pada semua formula biskuit untuk warna dan aroma berada pada nilai 3 (biasa), sedangkan rasa dan tekstur biskuit pada nilai 4 (enak untuk rasa dan renyah untuk tekstur). Hasil sidik ragam penerimaan panelis tidak berpengaruh nyata ( $p>0,05)$ terhadap mutu hedonik diantara formula biskuit, sehingga dilanjutkan pengujian bioavailabilitas mineral $\mathrm{Zn}$ dan Fe pada formula biskuit F2, F3, dan F4, sedangkan formula kontrol (F1) tidak dilakukan analisis bioavailabilitas karena tidak difortifikasi $\mathrm{Zn}$ dan Fe.

\section{Bioavailabilitas Fe dan Zn pada Biskuit}

Bioavailabilitas merupakan proporsi zat gizi yang dapat digunakan oleh tubuh secara aktual dari pangan yang dikonsumsi. Bioavailabilitas $\mathrm{Zn}$ dan $\mathrm{Fe}$ pada biskuit ikan gabus yang difortifikasi dengan taraf fortifikasi $\mathrm{Zn}$ dan $\mathrm{Fe}$ dapat dilihat pada Tabel 5 .

Tabel 5. Bioavailabilitas Fe dan Zn pada biskuit biskuit ikan gabus yang difortifikasi $\mathrm{Zn}$ dan $\mathrm{Fe}$

\begin{tabular}{ccc}
\hline Kadar fortifikan & \multicolumn{2}{c}{ Bioavailabilitas (\%) } \\
\cline { 2 - 3 }$(\%$ AKG/serving size $)$ & $\mathrm{Zn}$ & $\mathrm{Fe}$ \\
\hline F2 & $44,71^{\mathrm{a}}$ & $55,85^{\mathrm{a}}$ \\
F3 & $41,80^{\mathrm{a}}$ & $76,32^{\mathrm{a}}$ \\
F4 & $40,57^{\mathrm{a}}$ & $53,79^{\mathrm{a}}$ \\
\hline
\end{tabular}

Keterangan: Angka dengan superscript sama dalam satu lajur menunjukkan tidak berbeda nyata pada taraf kepercayaan $5 \%$

Data pada Tabel 5 menujukkan bahwa substitusi tepung terigu dengan tepung ikan gabus dan difortifikasi $\mathrm{Zn}$ dan Fe tidak mempengaruhi bioavailabilitas $\mathrm{Zn}$ dan Fe. Bioavailabilitas $\mathrm{Zn}$ dan $\mathrm{Fe}$ pada fortifikasi sebesar 50\% AKG/serving size berturut-turut adalah $41,80 \%$ dan $76,32 \%$. Biovailabilitas $\mathrm{Zn}$ lebih tinggi daripada bioavailabilitas $\mathrm{Zn}$ pada roti hasil fortifikasi yang sebesar 13,5\% (Lopez dkk., 2003).

\section{Sifat Fisik, Kimia, dan Daya Cerna Protein Biskuit Terpilih}

Pengamatan sifat fisik biskuit berupa uji tekstur bertujuan untuk menganalisis tingkat kekerasan (hardness) dengan menggunakan alat Texture analyzer dengan satuan gf (gramforce). Tingkat kekerasan pada produk biskuit dikaitkan 
dengan sifat kerenyahan. Kerenyahan biskuit akan semakin menurun dengan naiknya tingkat kekerasan. Biskuit ikan yang difortifikasi $\mathrm{Zn}$ dan $\mathrm{Fe}$, diperoleh tingkat kekerasan/ kerenyahan sebesar 925 gf dan uji yang sama pada biskuit komersial diperoleh kekerasan/kerenyahan sebesar $950 \mathrm{gf}$. Hal ini menunjukkan bahwa kerenyahan biskuit berbasis tepung ikan gabus yang difortifikasi dengan mikrokapsul Zn dan Fe lebih renyah dibandingkan biskuit komersial. Menurut Rebecca (2003), biskuit bayi dengan tingkat kekerasan antara 948-1196 gf mempunyai tekstur tidak terlalu keras dan tidak mudah hancur. Sifat kimia biskuit ikan yang difortifikasi $\mathrm{Zn}$ dan Fe dapat dilihat pada Tabel 6.

Tabel 6. Sifat kimia biskuit ikan yang difortifikasi $\mathrm{Zn}$ dan $\mathrm{Fe}$ (per $100 \mathrm{~g}$ )

\begin{tabular}{lcc}
\hline Komponen & Jumlah & Syarat mutu* \\
\hline Air $(\mathrm{g})$ & 2,73 & Maksimum 5\% \\
Abu $(\mathrm{g})$ & 2,08 & Maksimum 1,5\% \\
Protein $(\mathrm{g})$ & 13,34 & Minimum 9\% \\
Lemak (g) & 24,53 & Minimum 9,5\% \\
Karbohidrat (g) & 57,32 & Minimum 70\% \\
Besi (mg) & 11,17 & - \\
Zink (mg) & 8,83 & - \\
Daya cerna protein (\%) & 78,45 & - \\
Energi (kal) & 503 & Minimum 400 \\
\hline
\end{tabular}

Keterangan: *) SNI 01-2973-1992

Tabel 6 mencantumkan hasil analisis sifat kimia biskuit beserta SNI biskuit. Data menunjukkan bahwa kecuali karbohidrat; kadar air, abu, protein, dan lemak biskuit telah memenuhi SNI. Berdasarkan informasi dari WNPG (2004) yang menyatakan AKG balita (4-6 tahun) untuk $\mathrm{Zn}$ dan Fe sebesar 10,3 dan $9 \mathrm{mg} /$ hari, dapat dikatakan bahwa biskuit ikan gabus yang difortifikasi $\mathrm{Zn}$ dan Fe memenuhi AKG balita untuk Zn dan Fe.

Penentuan daya cerna protein menunjukkan bahwa daya cerna protein biskuit adalah $78,45 \%$. Ini berarti dari protein yang dikonsumsi sebesar $78,45 \%$ dapat dihidrolisis oleh enzim pencernaan menjadi fraksi yang larut. Nilai daya cerna biskuit tepung ikan gabus lebih rendah daripada biskuit tepung ikan lele dengan tambahan isolat protein kedelai yang memiliki nilai daya cerna protein sebesar 89,34\% (Mervina, 2009).

\section{Kontribusi Zat Gizi Biskuit}

Analisis kontribusi energi dan zat gizi biskuit terhadap AKG balita (4-5 tahun) dapat dilihat pada Tabel 7.
Tabel 7. Kontribusi energi dan zat gizi biskuit

\begin{tabular}{lccc}
\hline Energi/zat gizi & $\begin{array}{c}\text { Jumlah } \\
\text { (per 60 g) }\end{array}$ & $\begin{array}{c}\text { AKG balita (per } \\
\text { orang per hari)* }\end{array}$ & \% AKG \\
\hline Energi (kkal) & 302 & 1550 & 19,48 \\
Air (g) & 1,64 & - & - \\
Abu (g) & 1,25 & - & - \\
Protein (g) & 8,0 & 39 & 20,51 \\
Lemak (g) & 14,72 & - & - \\
Karbohidrat (g) & 34,39 & - & - \\
Fe (mg) & 6,7 & 9,0 & 74,44 \\
Zn (mg) & 5,3 & 9,7 & 54,64 \\
\hline Keterangan: *) WNPG (2004) & &
\end{tabular}

Menurut WNPG (2004), suatu bahan pangan dapat diklaim kaya akan suatu zat gizi apabila pangan tersebut mengandung paling sedikit 20\% AKG. Oleh karena itu, biskuit tersebut dapat dinyatakan sebagai kaya akan protein, juga mineral $\mathrm{Zn}$ dan Fe.

\section{KESIMPULAN}

Kandungan gizi biskuit berbasis $15 \%$ tepung ikan gabus yang difortifikasi $\mathrm{Zn}$ dan Fe per $100 \mathrm{~g}$ adalah 2,73 g air; $2,08 \mathrm{~g}$ abu,; 13,34 g protein; 24,53 g lemak;57,32 g karbohidrat; 503 kkal energi, serta 8,83 mg Zn dan 11,7 Fe. Kecuali karbohidrat, biskuit tersebut memenuhi standar kualitas menurut SNI. Dalam setiap serving size (60 g), biskuit dapat menyediakan $302 \mathrm{kkal}, 8 \mathrm{~g}$ protein, serta 54,64 g Zn dan 74,44 g Fe.

\section{DAFTAR PUSTAKA}

AOAC. (2000). Official Method of Analysis of the Associated of Official Analytical Chemists. Published by AOAC International, USA.

Astawan, M. (2009). Ikan gabus dibutuhkan pascaoperasi. http://cybermed. cbn.net.id. [28 April 2011].

Badan Penelitian dan Pengembangan Kesehatan (2007). Riset Kesehatan Dasar Tahun 2007. Jakarta(ID): Departemen Kesehatan Republik Indonesia.

Badan Penelitian dan Pengembangan Kesehatan. (2010). Basis data. http://www.litbang.kkp.go.id/basisdata. [10 Nopember 2012].

Caso, G., Scalfi, L., Marra, M., Covino, A., Muscaritoli, M., Mc Nurian, M., Garlick P.J. dan Contaldo, F. (2000). Albumin synthesis is diminished in men consuming a predominantly vegetarian diet. Journal Nutritiont 130: 528-533. 
Damayanthi, E. dan Rimbawan (2008). Penuntun Praktikum Evaluasi Nilai Gizi. Fakultas Ekologi Manusia. Institut Pertanian Bogor, Bogor.

Desai K.G.H. dan Park H.J. (2005). Recent developments in microcapsulation of food ingredients. Drying Technology 23: 1361-94.

Fitriani, S. (2001). Mikroenkapsulasi Besi untuk Fortifikasi Mentega. Skripsi. Fakultas Pertanian. Institut Pertanian Bogor, Bogor.

Herman, S., Griffin, I.J., Suwarti, S., Ernawati, F., Permaesih, D., Pambudi, D. danAbrams, S.A. (2002). Cofortification of iron-fortified flour with zinc sulfate, but not zinc oxide, decreases iron absorption in Indonesian children. American Journal Clinical Nutrition 76(4): 813-817.

Kumar, S., Rekha dan Sinha, L.K. (2010). Evaluation of quality characteristics of soy based millet biscuits. Pelagia Research Library 1(3): 187-96.

Kustiyah, L., Dwiriani, C.M. dan Anwar, F. (2010). Mikrokapsulasi Mineral Besi dan Seng dalam Pembuatan Makanan Tambahan untuk Balita Gizi Kurang. Laporan akhir Hibah Kompetitif Penelitian Strategis Nasional. Lembaga Penelitian dan Pengabdian kepada Masyarakat. Institut Pertanian Bogor, Bogor.

López, R.D., Bo, L. dan Brown, K. (2003). Absorption of zinc from wheat products fortified with iron and either zinc sulfate or zinc oxide. American Journal of Clinical Nutrition 78: 279-283.

Marcelino, G.T. (2012). Formulasi Cookies Fungsional Berbasis Tepung Ikan Gabus dengan Fortifikasi Mikrokapsul Fe dan Zn. Skripsi. Fakultas Ekologi Manusia. Institut Pertanian Bogor, Bogor.

Mervina (2009). Formulasi Biskuit dengan Subtitusi Tepung Ikan Lele Dumbo (Clarias Gariepinus) dan Isolat Protein Kedelai sebagai Makanan Potensial untuk Anak Balita Gizi Kurang. Skripsi. Fakultas Ekologi Manusia. Institut Pertanian Bogor, Bogor.

Moedjiharto, T.J. (2007). Ikan sebagai bahan substitusi human serum albumin (HSA) dalam penyumbang biofarma Indonesia. http://old-prasetya.ub.id. [28 April 2011].

Muchtadi, D. (2010). Teknik Evaluasi Nilai Gizi Protein. Penerbit Alfabeta, Bandung.
Nurilmala, M., Nurjanah dan Utama, R.H. (2009). Kemunduran mutu lele dumbo (Clarias gariepinus) pada penyimpanan suhu chilling dengan perlakuan cara mati. Jurnal Pengolahan Perikanan 12(1): 17-22.

Purnamasari, T. (2009). Fortifikasi Mikrokapsul Besi pada Permen Cokelat untuk Mengatasi Defisiensi Besi pada Remaja Putri. Skripsi. Fakultas Ekologi Manusia. Institut Pertanian Bogor, Bogor.

Rebecca, S. (2003). Pembuatan Biskuit untuk Makanan Sapihan dari Tepung Garut (Maranta arundinaceae L.). Skripsi. Fakultas Teknologi Pertanian. Institusi Pertanian Bogor, Bogor.

Rossana, E. (2009). Strategi Fortifikasi Zat Besi dengan Teknologi Mikroenkapsulasi dalam Upaya Pencegahan Anemia Defisiensi Besi pada Anak. Skripsi. Fakultas Kedokteran. Universitas Andalas, Padang.

Salvin, M. (1986). Atomic Absorption Spectroscopy. Chemistry Departemen Brook Haven National Laboratorium, New York.

Santosa, A.H. (2001). Ekstraksi Albumin Ikan Gabus (Ophiocephalus striatus). Skripsi. Fakultas Perikanan. Universitas Brawijaya, Malang.

Saunders, R.M., Connor, M.A., Booth, A.N., Bickoff, E.M. dan Kholer, G.O. (1973). Measurement of digestibility of alfafa protein concentrates by in vivo and in vitro methods. Journal of Nutrition 103: 530-535.

Soekarto, S. (1985). Penilaian Organoleptik untuk Industri Pangan dan Hasil Pertanian. Pusat Pengembangan Teknologi Pangan. Institut Pertanian Bogor, Bogor.

Susanto, H. dan Maslikah, S.I. (2011). Efek nutrisional tepung daun kelor (Moringa oleifera) varietas NTT terhadap kadar albumin tikus Wistar kurang energi protein. Publikasi Ilmiah Seminar Nasional MIPA 2011.

Standar Nasional Indonesia (1992). Mutu dan Cara Uji Biskuit SNI 01-2973-1992. Dewan Standarisasi Nasional, Jakarta.

Widyakarya Nasional Pangan dan Gizi VIII (2004). Prosiding, Angka Kecukupan Gizi dan Acuan Label Gizi, 17-19 Mei 2004, Jakarta. 